\title{
Institutional Environment and Capital Structure: Evidence from Private Listed Enterprises in China
}

\author{
Hongbo Duan (Corresponding author) \\ University Utara of Malaysia PHD Sintok \\ Kedah Malaysia \\ Hebei University \\ E-mail: duanhongbocn@126.com \\ Abdul Razak bin Chik \\ University Utara of Malaysia Sintok \\ Kedah Malaysia \\ Chonjun Liu \\ University Utara of Malaysia Sintok \\ Kedah Malaysia
}

Received: October 12, 2011

Accepted: October 27, 2011 Published: January 5, 2012

doi:10.5430/ijfr.v3n1p15

URL: http://dx.doi.org/10.5430/ijfr.v3n1p15

\begin{abstract}
With the rapid development of modern market economy, in order to safeguard the comprehensive competitiveness, enterprises adjust their capital structure based on the external and internal environment. In the selection of enterprises' financing policies, especially the debt decisions, the macroeconomic condition will be an important factor (Korajczyk and Leny). Studies suggest that macroeconomic condition has great impact on the pace and scale of the capital structure adjustment and the companies' liabilities (Dirk Hackbarth ect. 2006; Douglas O, Cook and Tian Tang, 2009). The capital structure determines structures of long-term debts and equity capital. The analysis on debt structure and benefits and risks of enterprises is of great importance to maximize the value of enterprises. On the basis of introducing the development of the capital structure theory, this article investigate an important issue in the area of financial economics by analyzing the main factors affecting capital structure and focusing on system environment which has not been fully studied. This article employed empirical method to analyze data of private enterprises in different areas during 2007-2009 which had been listed in Shanghai and Shenzhen stock exchange markets. The conclusion is that changes of the following five factors, government intervention degree, non-state-owned economic structure, market structure, financial structure of commercialization combine with legal system, have great impacts on the capital structure and the development of private enterprises.
\end{abstract}

Keywords: Institutional Environment, Capital Structure, Listed Companies

\section{Introduction}

The theory of capital structures is an important issue in financial economics. Since the Modigliani \& Miller (1958) published the capital structure irrelevance theorem, the theory and empirical research of capital structures have aroused great interest in financial circles (Harris \& Raviv, 1991). Until now, the academic community has developed a variety of capital structure theory. The factors which can change the capital structure include financing costs, company performance, internal human control, the owner layer of decision-making and so on. But in most studies, they believe the enterprise features is the only factor that affecting capital structure, while the institutional factors and macroeconomic environment are less to consider. To raise funds, different financing sources form a company's capital structure. Different ways of financing determine the enterprise's capital structure and its changes. Capital structure refers to the composition of capital and their mutual relations. As Company's capital comes from debt and equity, a 
company's debt structure significantly influences its operations and development.

The paper will use the narrow meaning of the debt structure. It refers to the structure and the proportional relationship of the components of a company's long-term debt. First of all, this paper will select a number of private listed companies. In theory, this article will discuss the affect of the institutional environment to their debt levels and make some useful assumptions. This article will select the variables to measure the change of the institutional environment and then build data regression model. Then, the paper uses PASW for data analysis. Finally, the article will be based on results of the analysis to explore the influence of external institutional environment, which affects the capital structure of listed private enterprises.

\section{Literature Review}

U.S. economists Modigliani and Miller made pioneering contributions for the theory of capital structure. With many strict assumptions, Modigliani and Miller (1958) concluded that: the corporate cost of capital is unrelated to its capital structure and the enterprise value and its capital structure are independent of each other. As a result, a large number of empirical analyses of factors affecting capital structure research have emerged. However, most studies of factors affecting the debt structure just include the enterprise features only, and less to consider institutional factors and the combined effects of the macroeconomic environment. Booth (2001) conducted an empirical study of 10 developing countries between 1980-1990 and it showed that capital structure may be determined by the ratio of tangible assets, tax rates, return on assets, size and country-specific factors. A company's capital structure is closely related to the following factors, such as its country's national factors, macroeconomic factors, market capital position, the tax system and so on. Many scholars have used empirical data from many countries find that different economic environment and institutional context are the important reasons for witch making differences in capital structure of various countries. Not only that, for the same country, different times of the macro-environment and different types of system-oriented also make the firm's capital structure show different in time and space. Macroeconomic environment is not only a direct impact on corporate capital structure's decision, but also distorts the enterprise features' the original influence on the capital structure (Braun and Larrain, 2005).

Research on China's financing behavior of listed companies and their capital structures ,Huang Song (2002) found that: unlike the U.S. counterparts, the overall level of China's listed companies are highly dependent on external financing, preferring equity financing rather than debt financing. China's capital structure studies are mainly based on state-owned enterprises and listed companies. To the capital structures of the state-owned enterprises, Yang Rui's study(1998) showed that: corporate system, financial system, financial system, the social security system and many other factors have led to debt ratio too high. But the incomplete capital system is the basic problem. Shi Donghui (2001), Huang Shao, Chang Gang (2001) analysis of equity financing preference of listed companies. From the point of view of the social and economic operation and development, in the broad level, the institutional environment has been interpreted as an academic that it has a direct or indirect role in binding and guiding the basic institutional arrangements, witch affect the behavior of all individuals and organizations to make decisions. According to Fan Gang (2009)" 1997-2007 Index of the Chinese market", the division of the institutional environment is basically overall affected by the following aspects: the degree of government intervention, non-state economic structure, market structure, financial market structure and legal institutional environment. These studies provide good conditions for this paper.

\section{Research Design}

From 1978, China has experienced from a planned economy to a market-based economy. Although China has achieved great success but there are also problems of uneven development. Regionally, some provinces, especially in the eastern coastal areas, the market has made decisive progress. However, in some provinces, the economic status of Sino-African market factors still important. In the public ownership system, the Government will impact on bank lending behavior directly, thereby reducing the cost of debt. This will help enterprises to obtain more long-term loans (Fan et al, 2004). Accordingly, this paper presents the first assumption:

H1: If the listed company in a higher degree of market-oriented, long-term liabilities in the firm's capital structure will be in the lower rate.

In November 1993, the CPC Central Committee pointed out: "The state should create conditions for equal participation in various economic sectors in market competition, equal treatment for all types of enterprises." 1999, China wrote the important position of non-state economy into the revised "Constitution." The introduction of these policies and regulations stimulated the non-state economy into the wider field. Non-state economy and the socialist public economy is different. It is an economic form which private means of production. It led to increasing competition in the market. Companies tend to reduce costs and optimize the financing structure in order to enhance its overall strength. In the 
financing structure, companies need more funding. They are more likely to obtain funds through various channels, rather than expand the capital stock alone. Thus, we propose the second hypothesis:

H2: In the market, the higher the proportion of non-state economy, the higher corporate's asset-liability ratio.

Wanzenried (2000) pointed out that the company's financial decision-making is heavily dependent on the characteristics of specific products in the market. In real life, a different competitive environment and product market structure, corporate financing policies are also different. Such as computers, real estate, electronics and other industries, product replacement fast. In this way, companies should not only reduce costs, but also continue to invest in upgrading the product and manufacturing standards. But in transportation, public utilities, energy and electric power industries, capital structure is determined mainly by the relationship of the demand and supply. They need a stable product and service prices and earnings' volatility is not so obvious. Asset-liability ratios of such monopoly industries are higher. Thus, this paper proposes the third hypothesis:

H3: The lower level of product market competition, enterprise asset-liability ratio will be higher.

Demirguc-kunt and Maksimovic (1996) studied the impact of the long-term financing on business performance in 30 countries. The results showed that the level of development of the stock market and banking sector are closely related to the business growth. Financial institutions can allocate funds professionally. They have the ability and have an incentive to monitor the use of funds side. Thus in a market economy, money is always flowing into the enterprise which has the high efficiency and good performance. Because the changing inflation rate will increase the transaction costs of both lenders and borrowers, so the company is more inclined to short-term liabilities. In general, the level of an area's financial intermediary development is higher; corporate financing environment has become more relaxed. In China, because of restrictions on equity financing, corporate debt financing will be more. Then we propose the fourth hypothesis:

H4: the level of development of the financial intermediaries and the debt ratio is positively correlated.

The 1990s, the corporate governance system rose in the world. It improved the system to protect investors by improving "Company Law", "Bankruptcy Law", and "Securities Law." Legal systems have different effects on different term debt. Legal system also affects the relationship between shareholders and creditors. With the strict legal system, the behavior of market financing will become more cautious. The risk will be less. Therefore, short-term liabilities of enterprises will be more. With the liberal legal system, the company would prefer to obtain long-term loans from financial institutions. So they will have a relatively stable funding. The more perfect the legal system, the higher the debt contract execution. It reduces the cost of signing. Therefore, short-term liabilities of enterprises will be more. Here, this paper presents the fifth hypothesis:

H5: A company which is in a good legal environment will have a relatively high short-term debt and relatively low long-term debt.

\section{Building the Model}

\subsection{Sample Selection and Data Sources}

This paper selected private enterprises which are in Shanghai and Shenzhen Stock Exchange among 1998-2007.We choose their 2007, 2008 and 2009 data. We removed ST, SST, * ST, or lack of data and samples of data anomalies. Finally, we get a total of 285 enterprises, 855 sample observations. They come from CSMAR database, which is developed by Co., Ltd. Shenzhen GTA. Firm characteristics and institutional data from a market-based environmental data index system, which was compiled by Fan Gang, etc. (2009), including various regions of China (including 31 provinces, autonomous regions and municipalities). As the state-owned companies are under government control, so private enterprise can be better to reflect the institutional environment's affect to the financing. But small and medium private companies' data is difficult to collect; this article uses data from the private listed companies.

\subsection{Model and Variable Definitions}

In order to test five hypotheses, we build a multiple linear regression model to analyze the how the institutional environment influence corporate debt structure. Equation to be tested:

$\mathrm{CS}=\alpha+\beta_{1} \mathrm{IE}+\beta_{2} \chi+\beta_{3} \mathrm{Ind}+\beta_{4}$ Year $+\varepsilon$

$\alpha$ is the intercept, $\beta_{1}-\beta_{4}$ is coefficient, $\varepsilon$ is the residual.

In the equation, 1. CS (Capital Structure) are explanatory variables, which said private listed company's capital structure. Academia is generally believed that the company's capital structure is the ratio of shareholders' equity and liabilities in the balance sheet, called the financial structure, financing structure or financial leverage. As the research needs, we 
define capital structure as a "Debt-to-long Capital Ratio ( DLCR)", "Total Debt to Total Assets (DTA)" and "Long-term Liability Rate (LTLR) ".

2. IE (Institution Environment) is the explanatory variables, which said the regional characteristics of the institutional environment. This article uses the "China market index" measuring regional institutional environment, which was written by Fan Gang, Zhu Hengpeng and Wang Lu (2009). The index reflects the extent of the market of the country's 30 provinces, municipalities and autonomous regions. This paper uses the following indicators: government intervention index (IndexGov), non-state economic structure index (IndexNES), the product market index (IndexIPR), financial market index (IndexFin) and the legal system index (IndexLaw) to be measured on the institutional environment.

3. $\mathrm{X}$ is a vector, which constituted by a number of control variables. We believe that the variables are: fixed assets (Tangible), profitability (EBIT), firm size (Size), and growth opportunities (Growth). They are firm characteristics which affect the debt financing.

$<$ Table 1 about here $>$

\section{Empirical Analysis}

\subsection{Descriptive Analysis}

\subsubsection{Descriptive Statistics}

Descriptive results show that China's level of government intervention in all regions, non-state economic structure, product market structure, financial development and legal environment do present a greater difference.

The following table is a description of the full sample results:

$<$ Table 2 about here $>$

\subsubsection{Pearson Correlation Test}

Table 5-2 lists the Pearson correlation test results of relevant variables. The results are Consist with expectations of Assumption 1, Assumption 2, Assumption 3. It shows that government intervention index (IndexGov), the product market index (IndexIPR) and the legal system index (IndexLaw), have a negative correlation between debt ratio. Index the greater the debt the less. Short-term liabilities increase relatively, while long-term liabilities decreased. Non-state economic structure index (IndexNSE) and financial market index (IndexFin) are negatively correlated with debt ratio, which are inconsistent with the Hypothesis 2 and Hypothesis 4.

\section{$<$ Table 3 about here $>$}

\subsection{Test Results of Multiple Linear Regression Analysis Model}

For testing the five elements of the institutional environment, we use 2SLS regression analysis, using the White (1980) heteroscedasticity correction. From the table we found that if private companies where the worse the degree of government intervention, the lower the level of product market, the more imperfect the legal system, the more inclined to raise proportion of long-term liabilities in capital structure. But IndexNSE have a significant effect on the capital structure. Regression analysis proved that this hypothesis 1, hypothesis 3 and hypothesis 5 are correct. To consider the control variables, the greater firm size, the more rapid growth. It is associated with the degree of capital structure and debt structure reduces. Similarly, the higher the level of corporate profits, the stronger its economic strength, and more likely to favor the Government, the long-term debt ratio will be greater.

$<$ Table 4 about here $>$

\section{Conclusions and Outlook}

This empirical results show that: if the degree of government intervention is stronger, the degree of product market is higher, the legal system is more robust, more private listed companies tend to choose short-term loans. By reducing the overall total liabilities ,they can enhance their level of competitiveness. When the proportion of non-state economy is greater, the level of financial sector development is higher, private companies prefer long-term loans to protect business operations and development. As market-oriented system in China is not perfect, only the government can promote private enterprise and national economic development. First, the Government should take reasonable control measures. Second, the government should improve the legal system. Third, the government should promote the development of financial markets. Finally, the Government must be fair treatment of non-state economy.

Due to limitations of study conditions and study space, this article does not strictly specify the special case of the institutional environment. In practice, there are many data collection problems, so the theoretical analysis of this article 
will have some limitations. This article does not discuss the links among the five elements of institutional environment. It also did not analyze the relationship between them, which affect the capital structure of private enterprises, especially the debt structure. Among them, the article did not discuss the risks and the practical application of methods. These will be my future research directions.

\section{References}

Duan, Hongbo, Han, Xiaojie. and Yang, H., An Analysis of Causes for SMEs Financing Difficulty, International Journal of Business and Management, vol. 4, No. 6, June 2009

Fan Gang, Wang Xiaolu, Zhu Hengpeng. China market index - the process of regional market relative to the 2009 Annual Report, Beijing: Economic Science Press, 2009.

Harris,M., \& ArturRaviv, 1991, The theory of capital structure,Journal of Finance46, 297-355. http://dx.doi.org/10.2307/2328697

Hu Xuyang. China IPO market-oriented system of quasi-empirical analysis of the effect of the reform - a perspective from the study IPO underpricing, Finance Essays, 2005,3

Johnson S.,Mitton T..Cronyism and Capital Controls:Evidence from Malaysia, Journal of Financial Economics, 2003.

Li Shenglan. Idea of private enterprise property rights protection assemblies, Institutional Economics, 2003,6

Modigliani,F., \& M.Miller, 1958. Thecostofcapital, corporation finance and the theory of investment, American Economic Review 48, 261-275.

Modigliani,F.,\&M.Miller,1963,Corporate income taxes and the cost of capital, American Economic Review53,433-443.

Sun Zheng, Liu Committee, Li Zengquan. Market-oriented, government intervention and corporate debt maturity structure of a listed company from China, empirical evidence, Economic Research, 2005,5

Wan Chaoling, Chu Cheng-Zhong, Xiang Li, Yuan Ye, Zhou Jianxin. Listed company's external research funding sources, the Shanghai Securities Research, 2002 Vol 1, 3 :147-175

Wang Wei, Shi Jinchuan. Barriers to entry and growth of private enterprise - Geely Group Case Study, Management World, 2005.7

Wang, Q., Wong, T.J., and Xia, L.J.,2005, "State Ownership,Institutional Environment and Auditor Choice:Evidence from China",Unpublished Working Paper.

$\mathrm{Wu}$ Xiaoqiu. The company's capital structure and quality of certain theoretical issues [J]. China Economic Information ,2003.5:64,66-69

Xia Lijun, Fang Yiqiang. Government control, environmental management and corporate value - Empirical Evidence from China's stock market, Economic Research, 2005,5

Xiaojie. Han, Hong. Duan, Based on the listed company's financial risks in hebei empirical research. E -Business and E-Government (ICEE), 2011 Shanghai, China

Yang Yong, Huang Manli, Song Min. Bank loans, commercial credit financing and corporate governance of listed companies in China, Nankai Business Review ,2009.12,28-37

Table 1. Variable Definition

\begin{tabular}{|c|c|c|}
\hline Variable & Abbreviated & Definition \\
\hline $\begin{array}{c}\text { Government } \\
\text { intervention } \\
\text { index } \\
\begin{array}{c}\text { Non-state } \\
\text { economic } \\
\text { structure index } \\
\text { The product }\end{array}\end{array}$ & $\begin{array}{c}\text { IndexGov } \\
\text { IndexNES }\end{array}$ & $\begin{array}{c}\text { Index is greater, the government intervention is less. } \\
\text { Index is greater, the proportion of non-state economy is } \\
\text { greater. }\end{array}$ \\
IndexLaw & Index is greater, the degree of product market is greater. \\
Index is greater, the level of financial market is higher.
\end{tabular}




\begin{tabular}{|c|c|c|}
\hline $\begin{array}{c}\text { market index } \\
\text { Financial market } \\
\text { index } \\
\text { the legal system } \\
\text { index }\end{array}$ & DAT & $\begin{array}{r}\text { Index is greater, the legal system is more complete } \\
\text { Total Debt / Total Assets }\end{array}$ \\
Total Debt to & Non-current liabilities / (non-current liabilities + \\
shareholders' equity) \\
Total Assets \\
$\begin{array}{c}\text { Debt-to-long } \\
\text { Capital Ratio } \\
\text { Long-term } \\
\text { Liability Rate } \\
\text { Fixed assets } \\
\text { Profitability } \\
\text { firm size } \\
\text { growth } \\
\text { opportunities }\end{array}$
\end{tabular}

Table 2. Main descriptive statistics of variables

\begin{tabular}{|c|c|c|c|c|c|}
\hline & $\mathrm{N}$ & Min & Max & Mean & Std.Dev. \\
\hline IndexGov & 855 & 0.4600 & 12.6700 & 9.1567 & 3.0912 \\
\hline IndexNSE & 855 & 3.1200 & 13.4400 & 11.1689 & 2.3766 \\
\hline IndexIPR & 855 & 6.3400 & 10.6100 & 9.7300 & 0.8113 \\
\hline IndexFin & 855 & 5.4700 & 12.0100 & 9.8731 & 1.5929 \\
\hline IndexLaw & 855 & 3.7600 & 16.6100 & 10.1196 & 3.8129 \\
\hline Tangible & 855 & 0.0006 & 0.8157 & 0.2533 & 0.1555 \\
\hline EBIT & 855 & -3.3406 & 1.8092 & 0.0674 & 0.1627 \\
\hline Size & 855 & 18.1569 & 24.4594 & 21.0754 & 0.8938 \\
\hline Growth & 855 & -1.0000 & 29.8168 & 0.2975 & 1.2623 \\
\hline DAT & 855 & 0.0091 & 4.1662 & 0.4466 & 0.2414 \\
\hline DLCR & 855 & 0 & 0.9895 & 0.1014 & 0.1227 \\
\hline LTLR & 855 & 0 & 0.8872 & 0.1222 & 0.1301 \\
\hline
\end{tabular}


Table 3. Pearson correlation test

\begin{tabular}{|c|c|c|c|c|c|c|c|c|c|c|c|c|}
\hline & $\begin{array}{l}\text { Index } \\
\text { Gov }\end{array}$ & $\begin{array}{l}\text { Index } \\
\text { NSE }\end{array}$ & $\begin{array}{l}\text { Index } \\
\text { IPR } \\
\end{array}$ & $\begin{array}{l}\text { Index } \\
\text { Fin }\end{array}$ & $\begin{array}{l}\text { Index } \\
\text { Law }\end{array}$ & Tangible & EBIT & Size & Growth & DTA & DLCR & LTLR \\
\hline IndexGov & 1 & & & & & & & & & & & \\
\hline IndexNSE & $.767^{* *}$ & 1 & & & & & & & & & & \\
\hline IndexIPR & $.578^{* *}$ & $.612^{* *}$ & 1 & & & & & & & & & \\
\hline IndexFin & $.729^{* *}$ & $.821^{* *}$ & $.705^{* *}$ & 1 & & & & & & & & \\
\hline IndexLaw & $.885^{* *}$ & $.740^{* *}$ & $.621^{* *}$ & $.833^{* *}$ & 1 & & & & & & & \\
\hline Tangible & $-.113^{* *}$ & -.001 & -.058 & .003 & $-.110^{* *}$ & 1 & & & & & & \\
\hline EBIT & .043 & $.091^{* *}$ & .042 & $.071^{*}$ & $.072^{*}$ & $-.161^{* *}$ & 1 & & & & & \\
\hline Size & -.043 & .050 & .022 & .037 & .006 & $-.082^{*}$ & $.100^{* *}$ & 1 & & & & \\
\hline Growth & .041 & .026 & .024 & -.003 & .009 & $-.102^{* *}$ & .056 & .041 & 1 & & & \\
\hline DTA & $-.075^{*}$ & -.027 & -.029 & -.033 & $-.091^{* *}$ & $.105^{* *}$ & $-.372^{* *}$ & $.225^{* *}$ & .012 & 1 & & \\
\hline DLCR & $-.096^{* *}$ & -.045 & $-.076^{*}$ & -.053 & $-.099^{* *}$ & .062 & $-.099^{* *}$ & $.319^{* *}$ & .015 & $.359^{* *}$ & 1 & \\
\hline LTLR & $-.094^{* *}$ & $-.074^{*}$ & $-.095^{* *}$ & $-.086^{*}$ & $-.090^{* *}$ & $.082^{*}$ & .012 & $.232^{* *}$ & .014 & $.069^{*}$ & $.782^{* *}$ & 1 \\
\hline
\end{tabular}

Note: **:At the 0.01 level (bilateral) is significantly related. *: At the 0.05 level (bilateral) is significantly related.

Table 4. Positive test results of hypothesis1-5

\begin{tabular}{|c|c|c|c|}
\hline & DAT & DLCR & LTLR \\
\hline IndexGov & $0.031^{* *}(0.421)$ & $0.037^{* * *}(0.478)$ & $0.019^{* * *}(0.236)$ \\
\hline IndexNSE & $0.038^{*}(0.616)$ & $0.002^{*}(0.029)$ & $-0.031^{* *}(-0.463)$ \\
\hline IndexIPR & $-0.006^{*}(-0.146)$ & $-0.065^{* *}(-1.425)$ & $-0.055^{* * *}(-1.159)$ \\
\hline IndexFin & $0.093^{*}(1.257)$ & $0.088^{*}(1.122)$ & $-0.036^{* *}(-0.449)$ \\
\hline IndexLaw & $-0.189^{* * *}(-2.258)$ & $0.153^{* * *}(-1.739)$ & $-0.011^{* * *}(-0.125)$ \\
\hline Tangible & $0.049^{*}(1.1538)$ & $0.055^{*}(1.644)$ & $0.103(2.984)$ \\
\hline EBIT & $-0.390(-12.518)$ & $-0.199^{* * *}(-3.622)$ & $0.011^{* * *}(0.313)$ \\
\hline Size & $0.264^{* * *}(8.529)$ & $0.335^{* *}(10.252)$ & $0.244^{*}(7.235)$ \\
\hline Growth & $0.028(0.920)$ & $0.015(0.479)$ & $0.015(0.464)$ \\
\hline Ind & Yes & Yes & Yes \\
\hline Year & Yes & Yes & Yes \\
\hline Cases & 855 & 855 & 855 \\
\hline F & 26.627 & 14.518 & 7.663 \\
\hline Adj-R ${ }^{2}$ & 0.213 & 0.125 & 0.066 \\
\hline
\end{tabular}

Note: * indicates significant at the 0.1 level. ** Indicates significant at the 0.05 level. *** Significant at the 0.01 level. 